\title{
Status Lymphaticus: Sudden Death in Children from "Visitation of God" to Cot Death
}

\author{
ANN DALLY*
}

During the seventeenth and eighteenth centuries, in cases of sudden death, coroners' verdicts of death by "visitation of God" became increasingly popular. This reflected growing reluctance to blame the dead person in a verdict of felo de se. Increasingly, sudden deaths were attributed to human accident. ${ }^{1}$ By the nineteenth century, as society became more secular and Christian ideas more sophisticated, belief in God's direct power waned, scientific medicine gained strength and "visitation of God" became less acceptable. A fatal "disease", status lymphaticus, was invented to fill the gap. This excited medical interest for some fifty years and is recorded as having killed thousands of people, mostly children. It was even regarded as "the most important problem in medicine". Later, though no "cure" had been found, it dropped from the textbooks so completely that today many younger doctors and medical historians have never heard of it.

During the nineteenth century, when biomedicine was developing, many "new" diseases were identified, described or invented. They can all be seen as reflections of changing social attitudes and values, particularly towards death, health and, in the case of some diseases, children. In the context of the development of the medical profession, they can also be seen as part of the changing structure of doctor-patient interactions and of the relations between doctors, medical institutions and the state.

Some of these diseases ceased to exist. They entered the textbooks with vigour, flourished for a while, and were often regarded as important diseases. Then, usually gradually, they were abandoned, considered to be non-existent, or reconstructed in a different way. Many of these disorders were the result of attempts to define and classify symptoms related to "hysteria" and to fit them into current beliefs. The search was always for anatomical variation that could appear to be causative, was evident at post-mortem and was backed by microscopical evidence. It was not always found.

Such "diseases" often incorporated not only current beliefs but also older ones. They included "suppressed gout", a relic of earlier times, and "railway spine", perhaps an early attempt to wrest money from insurance companies, ${ }^{2}$ later known familiarly as compensationitis. There was "ovariomania" and "hystero-epilepsy", reflecting the social influences on women and attitudes towards them. "Autointoxication" developed from the

*Ann Dally, MD, Wellcome Institute for the History of Medicine, 183 Euston Road, London NW1 2BE.

1 This is discussed extensively in Michael Macdonald, 'The secularization of suicide in England 1660-1800', Past and Present, 1986, 111: 50-97, and in Michael Macdonald and Terence R Murphy, Sleepless souls: suicide in early modern England, Oxford, Clarendon Press, 1990.

2 E M Caplan, 'Trains, brains, and sprains: railway spine and the origins of psychoneuroses', Bull. Hist. Med., 1995, 69: 387-419. 
idea that the body is poisoned by the contents of the large gut, a reflection of the Victorian obsession with constipation. In "floating kidney" and "visceroptosis" the internal organs were thought to have dropped, necessitating treatment by the new art of abdominal surgery. These diseases did not kill those who suffered from them, though some of the treatments devised for them did. None of them is recognized today though many of the symptoms and signs on which they were based are still with us. However, status lymphaticus did kill its victims, who were mostly healthy children. Many of them literally dropped dead.

Status lymphaticus (or status thymo- or thymico-lymphaticus or lymphatism) was defined as a disease that resulted in sudden death, mostly in children and young people, with apparently no specific cause, or only that of a small shock or trivial stress. It was nearly always fatal, though occasionally the patient was revived. Sudden, unexpected death was its main feature and it was seldom diagnosed while the patient was alive. Some even said diagnosis was impossible and that therefore the mortality rate was $100 \%$.

The disease was first described in 1889 by A Paltauf of Vienna and soon became prominent in the western world. ${ }^{3}$ The medical journals between 1890 and 1935 contain many case-histories, editorials and articles about it. In the American Surgeon-General's Catalogue for 1911 the list of references to status lymphaticus filled an entire column. In the next Series, 1931, they filled two columns. The current database of MEDline, which gives medical references since 1965 , does not even mention it.

In Britain, medical students were taught about this disease and its dangers at least until the 1950s. It also became important from the medico-legal point of view, particularly in distinguishing between natural and unnatural causes of death when the doctor did not know the cause or might be held responsible, or in exonerating a mother or nursemaid who might have "overlaid" her baby. In the 1950s one hospital pathologist attributed almost all difficult deaths to it. ${ }^{4}$ Yet now, as far as doctors are concerned, it does not exist and it never did exist.

We need to know something of how it came into being. During the nineteenth century many changes led to the description and delineation of status lymphaticus. There were, of course, the general changes affecting society and the medical profession, particularly secularization and humanitarianism, including slow and subtle changes in attitudes towards children. There were also specific changes that drew attention to sudden death in children. Such deaths had always happened occasionally (as they still do), but they were uncommon. It may be that increasing concern for children enhanced awareness of these fatalities but there was also a new kind of sudden death that was specifically associated with the medical profession. After 1847 deaths occurred during the administration of chloroform and occasionally of ether. These did not always concern children, but when they did, they attracted particular attention.

\section{Chloroform Deaths}

Ether was difficult to use. In Britain it was soon largely replaced by chloroform, which was easier, cheaper, less explosive and pleasanter for the patient. After Queen Victoria was

\footnotetext{
3 A Paltauf, 'Über die Beziehung der Thymus zum plötzlichen Tod', Wiener klinische Wochenschrift, 1889, 2: 877-81; idem, 'Über
}

plötzlichen Tod', Wiener klinische Wochenschrift, 1890, 3: 172-5.

4 Ian Tait, personal communication. 


\section{Ann Dally}

given chloroform in 1853, it became popular, but there was a snag. Every now and then a patient, usually a young person, died suddenly and unexpectedly under its influence. Estimates varied as to how often this happened. The commonest estimate of once in 2,000 to 3,000 anaesthetics was enough to cause alarm, but many thought it was more frequent. In an editorial of 1910, the Lancet informed its readers that it was "a well-known fact that only a small proportion of deaths under anaesthesia in private practice ever come to the notice of registrars or of coroners." 5 These deaths sometimes occurred after only a whiff of the vapour or during a minor surgical procedure and often to young patients who seemed to be in good health. Death occurred so suddenly that everyone was taken aback.

Individual chloroform deaths were chronicled in the medical journals. Week after week in the British Medical Journal and the Lancet, the Edinburgh Medical Journal, the Journal of the American Medical Association, Presse médicale and the many Germanlanguage medical journals there were case-histories and headlines- 'Another death from chloroform', 'Yet another death from chloroform', 'Two more deaths from chloroform', deaths at St Mary's, at Guy's, in Edinburgh, Boston, Paris, Berlin, and there were suggestions that many more such deaths occurred in private practice and were being covered up. ${ }^{6}$ Clearly the medical establishments throughout the western world were seriously worried about these deaths. Typically, the Lancet pronounced:

The profession and the public at large are ... becoming alarmed at the repeated instances of death brought on by the inhalation of chloroform, and it is for ourselves a melancholy duty to record these unfortunate instances. ${ }^{7}$

That was in 1853. It was to get much worse. In 1869 the British Medical Journal published a long editorial called 'Chloroform accidents' beginning, "Recent facts have been by no means encouraging as to any diminution in the dangers of anaesthetics" and comparing the situation to "a plank bridge across the Thames"-safe for some but "hardly to be recommended for general use". 8

Some doctors believed that the deaths were due to lack of skill on the part of anaesthetists but many revised this idea when they experienced one of these mysterious cases themselves. Then they were more inclined to think that there must be a specific pathological cause, something wrong with the patient that had not been detected. This is understandable. Reading through these cases it seems certain that some of the deaths were due to careless or inexperienced anaesthetists but equally clearly that some of them happened in experienced and careful hands. The Lancet bewailed the fact that "fatal cases have occurred with the most practised and scientific chloroformists". 9 and also "Chloroform takes away pain but it also takes away life". ${ }^{10}$

There were enquiries and committees and chloroform commissions but people still wanted to know why these deaths occurred.

\footnotetext{
5 Editorial, 'The responsibility of our hospitals under anaesthetics', Lancet, 1910, ii: 1022.

6 Ibid.

7 Lancet, 1853, ii: 409.
}

8 Brit. med. J., 1869, ii: 589-91.

9 Lancet, 1853, ii: 409.

10 M Flourens, quoted in Lancet, ibid. 


\section{Status Lymphaticus}

\section{Certification of Death}

The problem of chloroform death was made more urgent by another social change: the refinement of death certification. Increasingly there was a need to certify a death and to state the cause in an acceptable form. The description "died by the visitation of God" had been used at inquests in earlier times but was no longer acceptable. Compulsory registration of deaths had been introduced through the Births and Deaths Registration Act of 1836/7. Giving the cause of death was optional at first, but the trend towards accurate registration increased. In 1837 the Royal College of Physicians, the Royal College of Surgeons and the Society of Apothecaries circulated a joint paper that explained the need for accurate death certification and urged doctors to provide it.

In 1859 a publication called The nomenclature of disease was drawn up by a committee appointed by the Royal College of Physicians. Thereafter it was frequently revised. When a medical practitioner gave a cause of death that was unacceptable, the Registrar-General communicated with him in an attempt to elicit a more accurate diagnosis. ${ }^{11} 1874$ saw the passing of another Births and Deaths Registration Act. It now became compulsory to give the cause of death. The penalty for failure to give the required information was a fine of up to forty shillings.

Sudden unexpected death involved coroners' inquests. Since 1275 it had been the duty of the coroner to inquire into "cases of persons found drowned or suddenly dead". ${ }^{12}$ By the Coroners Act of 1887 the coroner was specifically ordered to differentiate between natural and unnatural death. It became important to the medical profession to have a respectable cause of these unexpected deaths that would lead to a verdict of death from natural causes rather than from misadventure or unnatural causes.

\section{Thymus Death}

For at least some of these deaths there was a possible explanation that accorded with current thinking. There was a long tradition of sudden death in infancy and early childhood related to noisy breathing and laryngeal obstruction. It was known as laryngismus stridulus. It was uncommon but here is a typical case in a one-year-old child with a history of "crowing fits", in 1844:

the child was sitting on the floor amusing itself with some playthings ... They saw the little thing stoop forward suddenly, as though in play ... As it remained in that position, however, they went to it, took it up, and found it dead. It had perished suddenly, no doubt in one of the paroxysms of laryngismus. ${ }^{13}$

Laryngismus stridulus was listed in the 1837 paper of the Royal Colleges on death certification. It was thought to be due to strangulation from pressure on the windpipe of an enlarged thymus gland. But this could not explain the mysterious deaths under anaesthesia.

\footnotetext{
11 Royal College of Physicians of London, The nomenclature of disease, London, Royal College of Physicians, 1859.

124 Edward I. st. 2.

13 James Reid, On infantile laryngismus; with observations on artificial feeding, as a frequent
}

\author{
cause of this complaint, and of other convulsive \\ diseases of infants, London, J Churchill, 1848, \\ quoted in J F Meigs and William Pepper, A practical \\ treatise on the diseases of children, 7th ed., London, \\ H K Lewis, 1883, p. 579.
}




\section{Ann Dally}

The thymus is a lymphatic organ that lies close to the thyroid gland in the front of the neck. It straddles the windpipe and, like other lymphatic tissue, it is relatively large in small children and gradually diminishes in size. We now know that it is important in the developing immune system but until the second half of the twentieth century, its function was unknown. In the late nineteenth century there was a trend in surgery to remove structures that the body could apparently do without.

Our distant forbears gave the thymus quasi-magical qualities. ${ }^{14}$ The new "scientific" doctors were unable to ascertain its function, so they tended to assume that it had none and sometimes removed it in an attempt to prevent its strangling the child. Before the twentieth century there was little effort to find the average size of the thymus or how much it varied between individuals. This variation turned out to be considerable.

The history of medical norms and how they are established is complicated and little explored. During the nineteenth century the concept of normality played an increasingly important part in clinical medicine and one could argue that it became one of its basic concepts. But there was (and often still is) carelessness in defining normality and this led to overdiagnosis and misdiagnosis, just as it does today. In the late nineteenth century little was known about the ways in which children differ from adults, and adult clinical standards were often applied to children. Some people realized that the thymus is large in infants and gradually declines but many doctors diagnosed as "large" any thymus that was not obviously small. ${ }^{15}$ This was usually done, not by weighing but from naked eye judgements at the post-mortem table. It was the exception to try to establish norms of weight even from post-mortem material, which introduces another complication.

Most children who died had suffered from severe or debilitating illness. It was not realized that such an illness diminishes the size of the thymus so that healthy children who die suddenly and unexpectedly tend to have bigger thymuses than others. It was assumed that a large thymus was a feature of sudden death and so was the cause of death. An example was the case of a previously healthy child of five who was found twitching and dying on a staircase. Its thymus was "large" and the cause of death was recorded as status lymphaticus. Next day a plumber was found twitching and dying in the same place. It was then discovered that there was a loose flap on the staircase that touched a naked cable that carried the city's electricity supply. ${ }^{16}$

The idea that a large thymus was a sign of health rather than of disease developed gradually. In the 1860 s the physician Samuel Wilks, who taught that the "plump and rounded bodies" of children with large lymph tissue was a sign of health, was apparently unusual in his belief. ${ }^{17}$ In 1904 the pathologist Leonard Dudgeon wrote: "We are able to judge with some degree of certainty the state of nutrition of a child by a macroscopical and microscopical examination of the thymus gland", but he did not deviate from the conventional view that children could be killed by their thymus glands. ${ }^{18}$

There had long been doubters. For instance, in 1886 even before status lymphaticus had been delineated, the shrewd Guy's physician Charles Fagge wrote in his textbook, "As a

\footnotetext{
14 'Narration-Thymos Primer', J. Am. med. Ass., 1969, 207: 1436.

15 H C Cameron, Mr. Guy's Hospital: 1726-1948, London, Longmans, Green, 1954, p. 133.

16 Regrettably, the reference for this incident has been mislaid.
} 


\section{Status Lymphaticus}

matter of fact, it is now certain that there is no relation whatever between laryngismus and the state of the thymus." 19 The clearest statement came much later, from the distinguished physician Humphry Rolleston in 1936. He commented on the thymus: "its real size is seen only in cases of sudden death in health, and these are the cases in which it is commonly regarded as enlarged". 20

In the nineteenth century it was widely believed that a large thymus could lead to sudden death. There was a double tradition concerning the thymus. In $1830 \mathrm{~J} \mathrm{H} \mathrm{Kopp} \mathrm{had}$ emphasized it and drawn attention to what he called thymic asthma-attacks of breathlessness on inspiration which sometimes led to death and were believed to be due to an enlarged thymus. In his opinion, they were caused by mechanical pressure from an enlarged thymus which could result in sudden death. ${ }^{21}$

There were also sudden inexplicable deaths without previous breathlessness but with a "large thymus". This was often equated with "laryngismus stridulus" or "laryngismus". Sometimes these conditions were regarded as variations of the same.

[It is] characterized by crowing inspirations, or by momentary suspension of the act of respiration; these attacks occur suddenly, and at irregular intervals, are of short duration, cease suddenly, and are unaccompanied by cough, or other signs of irritation of the larynx. If the disease progresses, it becomes associated with other convulsive symptoms, as strabismus, distortion of the face, carpopedal spasms, or general convulsions. ${ }^{22}$

It was sometimes classified with the neuroses and was thought to be due to strangulation by a large thymus gland. In one series of 30 cases, 24 of them were under one year and all were under four. ${ }^{23}$

Strangulation by the thymus gland was difficult to justify as the cause of sudden unexpected death without previous symptoms, for example, under chloroform. Some people postulated spasm of the glottis, but this was unsatisfactory. In 1858 a German physician, A Friedleben, wrote a book on the thymus and carefully studied the possibility of pressure causing death. ${ }^{24} \mathrm{He}$ concluded that it was unlikely that an enlarged thymus could mechanically obstruct the circulation or interfere with respiration, and announced, "There is no thymic asthma". But the popular view in the profession continued to be that pressure from an enlarged thymus could cause sudden death, and cases continued to be reported into the twentieth century.

\section{Status lymphaticus}

In 1889 and 1890, in two parts of the same investigation, Professor Paltauf gave an explanation that fitted the need. He doubted that mechanical pressure of the thymus could kill. He had examined many corpses after unexplained sudden death and described

19 C H Fagge, Textbook of the principles and practice of medicine, London, J \& A Churchill, 1886, p. 784.

20 Sir Humphry Davy Rolleston, The endocrine organs in health and disease, London, Oxford University Press, 1936, p. 439.

21 J H Kopp, Denkwürdigkeiten in den ärztlichen Praxis, Frankfurt, J C Hermann, 1830.
22 Meigs and Pepper, op. cit., note 13 above, p. 579.

23 Ibid., p. 577.

24 A Friedleben, Die Physiologie der Thymusdrüse in Gesundheit und Krankheit vom Standpunkte experimenteller Forschung und klinischer Erfahrung, Frankfurt, Literarische Anstalt, J Rütten, 1858. 


\section{Ann Dally}

widespread hyperplasia of the lymphoid tissues. He postulated that there was a peculiar "lymphatico-chlorotic" constitution in which there was enlargement of all lymphoid tissues and which caused a predisposition to sudden death. ${ }^{25} \mathrm{He}$ linked it to the "hypoplasia of the heart and aorta similar to that described by Virchow in chlorotic subjects". This came to be called status lymphaticus or status thymicolymphaticus. Like the other pathologists, Paltauf gave no measurements and no standards of normality or abnormality.

This theory fitted comfortably into current theory, with its ideas about diathesis, a constitutional tendency towards disease or a particular disease, related to the idea of disease as an imbalance of humours and increasingly thought to be related to decline and degeneration. Sudden, "thymic", death was now regarded as the result of a condition inherent in the patient, who was predisposed to sudden death from trivial causes. Some people combined the new theory with the old, for instance in 1888, P Grawitz, a distinguished German pathologist, suggested that suffocation by an enlarged thymus was the immediate cause of death but was secondary to a primary, "constitutional" disorder involving hyperplasia of the thymus, rickets, and a generalized swelling of the lymph glands. ${ }^{26}$ Such explanations absolved the increasingly anxious anaesthetists from blame.

The idea caught on, though not everyone accepted it. Some people continued to hold the older views. The conclusion that diathetic imbalance was the underlying explanation satisfied both sides. It provided an explanation for the awkward fact that the actual cause of death could not be attributed to any single post-mortem finding. It exonerated clinicians, surgeons, anaesthetists and pathologists. It was such a satisfying explanation that the diagnosis was accepted for the next sixty years. A subsequent researcher, C Hart, counted more than 820 papers on the subject published in the next thirty-two years. ${ }^{27}$ Pathologists and clinicians who believed it included Virchow, Cohnheim, Jacobi, Rauchfuss, Somma, Grawitz, Berthold and Beneke. ${ }^{28}$ In Britain it created much interest. It was widely believed that a typical status lymphaticus death was a child who saw his friend nearly run over and immediately himself dropped dead.

The race was now on to diagnose status lymphaticus before sudden death occurred, and to apply treatment that would prevent it. This was even more urgent after the introduction of the antitoxin for diphtheria, which came onto the market in 1892 and soon became a routine treatment. The mortality from diphtheria fell rapidly but some patients died suddenly when given it. One of these deaths received a lot of publicity. In 1896 Professor Paul Langerhans (of the islets fame) gave the antitoxin to his son. The child died instantly. $^{29}$

Almost everyone seems to have believed in the theory of a lymphatic diathesis predisposing to sudden death. In $1898 \mathrm{Sir}$ William Osler discussed the "lymphatic constitution" whose subjects "have a diminished vital resistance, and are especially prone to fatal collapse under ordinarily very inadequate exciting causes." 30 Others linked the

25 Paltauf, 'Ueber die Beziehung der Thymus', and Paltauf, 'Über plötzlichen Tod', both op. cit., note 3 above.

26 P Grawitz, 'Über plötzliche Todesfalle im Säuglingsalter', Deutsche medizinische Wochenschrift, 1888, 22: 429-31.

27 C Hart, Die Lehre vom Status ThymicusLymphaticus, Munich, 1923, p.7.

\footnotetext{
28 Discussed in Warren G Guntheroth, 'The thymus, suffocation, and sudden death syndrome: social agenda or hubris?', Perspect. Biol. Med., 1993, 37: 2-13.

29 Discussed in Rolleston, op. cit., note 20 above, pp. 482-5.

$30 \mathrm{~W}$ Osler, The principles and practice of medicine, 3rd ed., Edinburgh and London, Young J Pentland, 1898, pp. 827-8.
} 


\section{Status Lymphaticus}

condition with exophthalmic goitre and large adenoids. ${ }^{31}$ The idea developed that children with status lymphaticus were well fed, pale, pasty, flabby and rather inert and effeminate, with large thymus and tonsils. This verbal picture was repeated many times, at least until the mid-twentieth century. Clifford Allbutt and Humphry Rolleston (or John Thomson, who wrote the section in their textbook in 1908) were more sceptical but accepted the theory pro tem-and said that there was no treatment. ${ }^{32}$

It is not surprising to find that anaesthetists were especially keen on the theory. As one of them wrote: "The most important thing to us as anaesthetists is the diagnosis of this condition." 33 Once the diagnosis was established and accepted, it exonerated many doctors. For instance, in 1909, in the case of a sudden death attributed to persistent thymus, the Lancet commented that "the circumstances of the death might have sustained a charge of manslaughter in the absence of a necropsy." 34 Clearly trying to protect the profession, the Lancet also emphasized the importance of diagnosing the condition lest death be attributed to "anaesthetic, poisoning or overdosage" or "wrongly attributed to drug toxaemia". 35

Some said there was no treatment ${ }^{36}$ but there was treatment. It was the surgical operation of thymectomy (the removal of the whole gland). Since the thymus had no known function and its absence was compatible with life, its removal would, it was argued, remove the likelihood of sudden, unexpected death. In the 1890s the German surgeon Rehn reported success in removing or fixing the thymus, thereby reviving the theory that it could obstruct the airway and strangle the child. ${ }^{37}$ In 1906 at the Surgical Congress, König advised complete thymectomy and recommended that the organ be drawn out, resected, or stitched to the sternum. In 1908 the anaesthetist W J McCardie assured his readers that cases had been "cured" by the operation. ${ }^{38}$ In the same year Osler's textbook stated, "the possibility of an antemortem diagnosis, as well as of therapeutic measures, has been demonstrated beyond any doubt." 39 But when surgery became the treatment of choice, the mortality was unacceptably high. In one series it was 33.3 per cent, 1 in 3 patients, and this was an operation done on apparently healthy children without symptoms and with few if any signs. ${ }^{40}$ Once this was generally known, few (or at least fewer) continued to recommend the treatment.

Meanwhile, X-rays had been discovered. More and more uses were being found for them. In $1903 \mathrm{H}$ Heinecke reported that exposure of animals to X-rays indicated that

31 George Blumer, 'The relation of the status lymphaticus to sudden death, death under anaesthesia, and infection', Bull. Johns Hopkins Hosp., 1903, 14: 270-3.

32 John Thomson, 'Status lymphaticus', in Sir Clifford Allbutt and Humphry Davy Rolleston, $A$ system of medicine, 9 vols, 2 nd ed., London, Macmillan, 1905-1911, vol. 4 (pt 1), p. 483. John Thomson was Physician to the Royal Hospital for Sick Children, University of Edinburgh.

33 W J McCardie, 'Status lymphaticus in relation to general anaesthesia', Lancet, 1908, i: 196-202, see pp. 198-9.

34 Lancet, 1909, i: 1899.

35 'The annus medicus', Lancet, 1909, ii: 1899-900.

\footnotetext{
36 For example, Thomson in Allbutt and Rolleston, op. cit., note 32 above.

37 Dr Berthold, 'Über plötzliche Todesfalle der Kinder, speciell der Säuglinge', Archiv für Kinderheilkunde, 1898, 24: 186-9, 429-31.

38 McCardie, op. cit., note 33 above, p. 199.

39 Aldred Scott Warthin, 'Diseases of the Thymus', in William Osler and Thomas McCrae, Modern Medicine: its theory and practice, 7 vols, Philadelphia and New York, Lea Brothers, 1907-1910, vol. 4, p. 785.

40 Russell L Cecil, A textbook of medicine, 5th edn, Philadelphia and London, W B Saunders, 1940, section on 'Diseases of the thymus gland' by A Graeme Mitchell, pp. 1338-41.
} 


\section{Ann Dally}

lymphoid tissue was more sensitive to X-rays than were other tissues and that exposure to X-rays led to diminution in size. ${ }^{41}$ This seemed to be just what was needed. In $1907 \mathrm{~A}$ Friedländer treated with $\mathrm{X}$-ray a child diagnosed as having status lymphaticus. ${ }^{42}$ Its thymus shrank. Soon irradiation was the treatment of choice where a large thymus was suspected. Virtually every textbook of the period recommended it. There were even suggestions that all newborn babies should be irradiated as a prophylactic measure. ${ }^{43}$ Newspaper articles spread the idea spread among physicians and lay people that respiratory symptoms in children, especially breath-holding attacks, indicated thymic hypertrophy that required X-ray treatment. It has been called an "epidemic"44 and it continued for half a century. In 1932 the pathologist William Boyd wrote, "The situation has come to such a pass that the surgeon who does not have the child with a wide shadow treated by irradiation before the administration of an anaesthetic may be held liable for malpractice if the child dies while under anaesthesia." 45 In 1936 Sir Humphry Rolleston wrote, "a fatal result has been frequent in the past; but should be less so if X-ray exposures of the thymus are adopted early." 46 This advice was widely repeated.

By 1910 it was known that exposure to X-rays could cause cancer ${ }^{47}$ and that there was a long induction period but no one seems to have linked this with the irradiation of babies thought to have "large" thymuses.

In 1911 the diagnosis of status lymphaticus was recognized as an official cause of death in England and Wales. In that year it was held to be responsible for 121 deaths, nearly all of them children. ${ }^{48}$ Status lymphaticus was recorded as causing three deaths per million living persons. ${ }^{49}$ In addition, 444 deaths over the age of one year were attributed to "Syncope, Sudden Death".

There were more official efforts to counteract the idea that anaesthetics were dangerous. In 1911 , in addition to those classified as primary status lymphaticus, twenty-five deaths that occurred during anaesthesia were recorded as being "related to the condition that led to the administration of an anaesthetic", nearly always chloroform. In five of these the nature of the anaesthetic was not mentioned and all except one of the rest had received chloroform or chloroform mixture. Only one had received another anaesthetic (ethyl chloride). Chloroform deaths were causing anxiety and general bemusement. The official attitude is reflected in the wording of the Registrar-General's Report: "Apparently the status lymphaticus seldom causes death during the administration of ether. The operations during which these deaths occurred seem for the most part not to have been of a dangerous nature." 50 This line of thought influenced a change in registration practice regarding death

41 H Heinecke, 'Über die Einwirkung der Röntgenstrahlenauf Tiere', Münchener medizinische Wochenschrift, 1903, 50: 2090-2.

42 A Friedländer, 'Status lymphaticus and enlargement of the thymus: with report of a case successfully treated by the X-ray', Arch. Pediatr., 1907, 24: 490-501.

43 A Moncrieff, 'Enlargement of the thymus in infants with special reference to clinical evidence of so-called status thymico-lymphaticus', Proc. r. Soc. Med., 1937, 31: 537-44.

44 F N Silverman, 'A la recherche du temps perdu and the thymus (with apologies to Marcel Proust)', Radiology, 1993, 186: 310.

$45 \mathrm{~W}$ Boyd, "The weight of the thymus gland in health and disease', Am. J. Dis. Child., 1936, 51: 313.

46 Rolleston, op. cit., note 20 above, p. 447.

$47 \mathrm{Z}$ M Bacq and Peter Alexander, Fundamentals of radiobiology, 2nd ed., London, Pergamon Press, 1961.

48 Registrar-General, 74th annual report, London, HMSO, 1911, p. 206.

49 Ibid., p. 56.

50 Ibid., p. xciv. 


\section{Status Lymphaticus}

under anaesthesia. "[I]t seems illogical to class deaths primarily to anaesthetics, since the primary cause must always be some condition which has occasioned the administration of an anaesthetic." 51

So the Registrar-General had decided to tabulate as a secondary classification all deaths where there was a mention of anaesthesia. There were 276 in England and Wales that year, fairly evenly spread between the sexes aged from one to over sixty-five. Status lymphaticus was held to have caused thirty-one of these, all of them male. He did not explain the omission or absence of female deaths. ${ }^{52}$ In a later report he attributed the excess death rate in males to operations for hernia and phimosis in infants. ${ }^{53}$

By this time irradiation of the thymus in children was becoming a standard prophylactic measure before surgery or anaesthesia ${ }^{54}$ but more critical attitudes and appraisals were beginning to emerge. For example, pathologists were actually weighing and measuring the thymus. As long ago as 1832 Astley Cooper had summed up the literature and concluded that the thymus weighs $1 / 2 \mathrm{oz}(15 \mathrm{~g})$ at birth, continues to grow for two years, then atrophies. ${ }^{55}$ The first edition of Gray's Anatomy (1858) gave much the same information. Various and varying weights were published. In 1898 Osler referred merely to "hyperplasia" and "enlargement" but gave no weights. ${ }^{56}$ In 1904 Dudgeon wrote, "It is doubtful whether we ought to give any exact normal weight for this gland". ${ }^{57} \mathrm{He}$ emphasized the enormous variation in existing records, which he then summarized, warning that "We must be careful, however, not to put too much stress on the weight of the thymus". ${ }^{8}$ Nearly half a century later Sir Geoffrey Keynes found the need to write, "It seems to be extraordinarily difficult to get at the truth concerning even the size of this enigmatic organ". $59 \mathrm{He}$ drew attention to the wide variations, having found weights of adult organs varying between $2.7 \mathrm{~g}$ to $32 \mathrm{~g}$ and said the condition was "a great standby for coroners ... There is much comfort to be derived from the application of a familiar label, even though it is really no more than a confession of ignorance." It seems likely that this helped the "disease" to last so long with so little evidence to support it. In spite of the evidence against it, it continued to suit people's beliefs, hopes, and fears.

The "familiar label" of status lymphaticus continued to be applied. X-rays and still occasionally surgery were increasingly recommended for "enlarged thymus", usually diagnosed by percussion and X-rays. Yet percussion of the chest of a small infant is an unreliable way of assessing the size of the underlying organs. So was X-ray, particularly when the standard of normality for X-rays of the chest was worked out on adults standing upright and holding their breaths. A baby will not stand up and hold its breath. Its anatomy also differs from the adult and changes rapidly during the weeks after birth. So does the $\mathrm{X}$-ray picture of heart and lungs. The big shadow in the middle of the chest varies in size according to respiration and heartbeat. It also varies according to the angle of the beam with which the radiograph is taken, which is different in a baby from an adult. So it is

51 Ibid., p. xcii.

52 Ibid., p. xciii.

53 Registrar-General, 82nd annual report, London, HMSO, 1919, pp. 54 and xcvi.

54 A Friedlander, 'Enlargement of the thymus treated by roentgen ray', Arch. Pediatr., 1917, 34: 441-3.

55 Sir Astley Cooper, The anatomy of the thymus

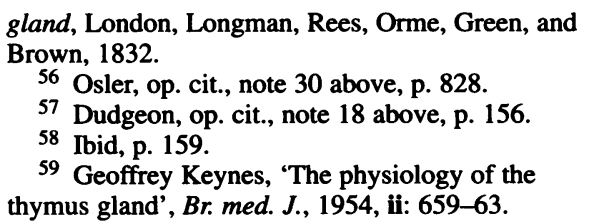
thymus gland', Br. med. J., 1954, ii: 659-63. 
difficult to know what you are looking at. But it was to be many years before the ability to assess the size of the thymus by this means was questioned and eventually rejected. This is a typical example of lack of attention to norms before diagnosing abnormality.

Savill's System of clinical medicine, much used by students and practitioners, emphasized the success of X-rays in the treatment of status lymphaticus and recommended them as "the method of choice". 60 The first edition of Price's Textbook of medicine, published in 1922, recommended that "operation and removal of the thymus must be considered without delay" when the diagnosis had been made, the alternative treatment being X-rays. ${ }^{61}$ In a later edition, Lord Horder (and $\mathrm{J} \mathrm{W} \mathrm{McNee)} \mathrm{pointed} \mathrm{out}$ that the diagnosis was usually made only in the post-mortem room, but praised the use of $\mathrm{X}$-rays in diagnosis. ${ }^{62}$

A Swedish pathologist, J A Hammar, devoted many years to the study of the thymus, including the normal thymus. He produced much evidence to suggest that status lymphaticus was not a valid disease entity and he denied the existence of "thymus death". ${ }^{63}$ In 1923 an extensive review criticized the lack of rigorous analysis in the literature, rejected the idea of thymic suffocation and argued that there was little firm evidence of status lymphaticus. ${ }^{64}$

But the conditions that created a "need" for the disease continued to exist. While pathologists were beginning to question, anaesthetists were increasingly certain of the diagnosis. There is a marked difference in the literature of the two professions. A growing number of anaesthetists and others wrote on the subject of status lymphaticus, taking its existence for granted and stressing the importance of diagnosing the condition in advance and the difficulty of doing so. ${ }^{65}$ One stated "there is no disease of greater medico-legal importance" and some urged that a Royal Commission be appointed to look into it. 66 Others drew attention to the success of surgery or of "cure" following "application of Xrays to the throat". 67

Status lymphaticus was diagnosed so widely and seemed to be such a problem that Professor Edward Emrys-Roberts organized an ad hoc committee to enquire into it. In 1925 the members came out strongly against even the existence of the condition but there were too few records to deduce any authoritative conclusions. ${ }^{68}$

The following year, 1926, a committee of investigation was formed by the Medical Research Council and the Pathological Society of Great Britain and Ireland. It consisted largely of pathologists who had seen cases of status lymphaticus only in the mortuary. In a preliminary report they concluded that the normal thymus varied considerably in size

\footnotetext{
60 Thomas Dixon Savill, A system of clinical medicine, dealing with the diagnosis, prognosis, and treatment of disease, for students and practitioners, 5th ed., London, E Arnold, 1918.

61 Frederick W Price (ed.), A textbook of the practice of medicine, London, $\mathrm{H}$ Frowde, Hodder \& Stoughton, 1922, p. 424.

62 Frederick W Price (ed.), A textbook of the practice of medicine, 2nd ed., London, $\mathrm{H}$ Milford, Oxford University Press, 1926, p. 845.

63 J A Hammar, 'Ueber Gewicht, Involution, und Persistenz der Thymus im Postfötalleben des Menschen', Archiv für Anatomische
}

Entwicklungsgeschichte, 1906, pp. 91-182 (quoted in Rolleston, op. cit., note 20 above, p. 439).

64 Hart, op. cit., note 27 above.

65 For example, McCardie, op. cit., note 33 above, and also Donald J Munro, 'The status lymphaticus', Lancet, 1909, ii: 1468-9.

66 R Ernest Humphry, 'Status lymphaticus', Lancet, 1909, ii: 1703-5.

67 W C Bosanquet, 'Diseases of the thymus', in Allbutt and Rolleston, op. cit., note 32 above, vol. 5, p. 673.

68 Medical Research Council Report, 'Status lymphaticus', J. Pathol. Bact., 1925, 28: 132. 


\section{Status Lymphaticus}

and that in cases of sudden death there was no greater incidence of large thymuses than would be expected by chance. They insisted "there is no evidence to show that there is any connection between the presence of a large glandular thymus and death from unexpected or trivial causes". ${ }^{69}$ In 1927 an extensive analysis of deaths from status lymphaticus announced as "a critical examination of a curious phase of modern medical teaching", 70 said that diagnosing in life was "largely nonsense", 71 and that if thymic weight is the criterion, status lymphaticus and its associated conditions were "mere verbalisms". ${ }^{72}$ Such a diagnosis has "no more value than affirmative evidence in cases of witchcraft" and "the diagnosis ought to be abandoned."

In cases of sudden death, the old inquest verdict of "Died by the visitation of God" is at least as scientific as and more modest than "Status [Thymicus" or] "Lymphaticus"; "Cause unknown" is to be preferred [to either and] [t]he present use [of these terms] in certification and in evidence in coroners' courts ... is, we suggest, a good example of the growth of medical mythology. A nucleus of truth is buried beneath a pile of intellectual rubbish, conjecture, base observations and rash generalisation. This heap of rubbish is described in the current scientific jargon and treated as an orthodox shrine. ${ }^{73}$

The authors referred to "an uncanny fourth dimension of medicine, where the familiar canons and methods of scientific criticism are becoming foolishness, where fact and hypothesis are habitually confounded and nothing is but what is not."74

The final report of the MRC Committee was not published until 1931. Based on 680 postmortem examinations, it established that the normal thymus may weigh as much as 70 or $80 \mathrm{~g}$ up to the age of sixteen and may be substantial at any age and that there was no significant deviation in size in any group of patients and no hypertrophy of other lymphoid tissue. ${ }^{75}$

But many disagreed with this and there were protests in the medical journals. Some of it came from clinicians, who objected that the evidence came only from the post-mortem room and ignored the living. Some of the objections came from the post-mortem room itself. As late as 1945 a pathologist published the angry statement, "The now popular attitude that there is no such thing as Status . . . Lymphaticus can be quickly dissipated by autopsy studies in any Coroner's office where children are studied". ${ }^{76}$

In 1931 the final report of the MRC committee fully supported the previous conclusions that there was no such condition as status lymphaticus. ${ }^{77}$ The Lancet published an editorial called 'The end of status lymphaticus', saying, "it is simple humanity to search for some explanation which will satisfy the modern mind where the 'visitation of God' would once have been enough. Hence the doctrine of 'status lymphaticus' which, owing to our ignorance of the anatomy of the normal healthy human body, has survived longer than it should."78

69 Ibid., p. 213 (italics in the original).

70 M Greenwood and H M Woods, "'Status thymo-lymphaticus" considered in the light of current works on the thymus', J. Hyg., 1926, 26: 305-26, p. 307.

71 Ibid, p. 312.

72 Ibid., p. 324.

73 Ibid., p. 325.

74 Ibid., p. 324-5.

75 M Young and H M Turnbull, 'An analysis of the data collected by the status lymphaticus investigation committee', J. Path. Bact., 1931, 34: 213-58. This commented on the Medical Research Council and Pathological Society enquiry. For analysis see editorials in $\mathrm{Br}$. med. J., 1931, i: 468-9, and Lancet, 1931, i: 593-4.

76 J L Carr, 'Status thymo-lymphaticus', J. Pediatr., 1945, 27: 1-43.

77 Young and Turnbull, op. cit., note 75 above.

78 Editorial, 'The end of status lymphaticus', Lancet, 1931, i: 593-4. 


\section{Ann Dally}

Some people were angry. Unimpressed by the accumulated evidence against the disease, they were severely critical of the suggestion that it did not exist. A typical letter in the British Medical Journal stated,

One would have thought that if any field of human endeavour was to escape the craze for settling things by committees that field was medicine ... [T] he profession ought to look askance at the reinstitution of medieval methods of arriving at the truth. A committee once decided that the earth does not move. ${ }^{79}$

Among these objectors was Alan Moncrieff, Professor of Child Health at the Hospital for Sick Children, Great Ormond Street-a powerful position. He was also medical correspondent to The Times. He remained convinced that one could diagnose an enlarged thymus clinically and with X-rays and that, once diagnosed, it should be irradiated. At a meeting at the Royal Society of Medicine in 1937 he described twelve young children with symptoms "which appeared to be associated with enlargement of the thymus gland as shown on X-ray examination of the thorax" ${ }^{80} \mathrm{He}$ pointed out that the MRC committee had been concerned with "pathological material only" since they believed that the condition could not be diagnosed during life and the other evidence was also concerned with post-mortem material. He said that it was now possible, radiologically, to obtain knowledge of the size of the thymus during life. Size could be varied by treatment and symptoms disappear after treatment. He protested at the Lancet leader that had proclaimed the end of the condition. ${ }^{81} \mathrm{He}$ showed X-rays of the chests of patients whom he had irradiated and stated that, in his opinion, "syncope, dyspnoea and fits in young infants, associated with thymic enlargement, does not appear to have been recognized sufficiently in this country", 82 insisting that, "as soon as possible after an enlarged thymus has been proved by X-ray examination, in an infant displaying the alarming symptoms recorded above, the size of the thymus should be reduced by suitable radiation." He said that he did not have the courage to withhold such treatment while trying out other forms of therapy. ${ }^{83}$

Moncrieff was strongly criticized in the ensuing discussion. One critic doubted whether the wide variety of symptoms that he described could all be caused by thymic enlargement and also questioned his interpretation of X-rays, pointing out that the mediastinal shadow varied with respiration. Others were also critical. Moncrieff was unmoved and one of his former house physicians told me that many years later he was still irradiating thymuses.

Meanwhile chloroform had gone out of fashion, its dangers widely recognized. It was now seldom used except in induction (mixed with ether) and in emergencies. Increasingly, reports indicated that symptoms attributed to status lymphaticus were due to other causes. Status lymphaticus was splitting up into different entities, and chloroform deaths were being attributed to chloroform. From the late forties there were reports of "cot death" as a separate condition and attention began to focus on that. Other anaesthetics such as Trilene were becoming available. This lessened the need for the existence of status lymphaticus.

In 1939, Henry Cohen wrote, "The term 'status thymico-lymphaticus' is, on the present evidence, a meaningless term giving an air of profundity to what is a confession of ignorance, for it can mean only that 'this person has died suddenly from an unexplained

79 Temple Grey, Br. med. J., 1931, i: 513.

80 Moncrieff, op. cit., note 43 above.

81 Lancet, op. cit., note 78 above.
82 Moncrieff, op. cit., note 43 above, p. 543.

83 Ibid., p. 544. 
or trivial cause'."84 Yet in the same year the eleventh edition of Savill's book still listed status lymphaticus as a cause of sudden death and said that X-ray treatment "appears to be successful". 85

Paediatricians remained divided. The American, Emmett Holt Jr wrote in 1940: "It is clear now that the supposed hyperplasia of the lymphatic structures and thymus in socalled status lymphaticus is physiological in young, well-nourished individuals", 86 and, "Satisfactory standards for the median and mean width of the supracardiac shadow and for the limits of the normal width at different ages have never been established. Moreover, supposedly pathologically wide supracardiac shadows have been found in from 25 to 50 per cent of healthy infants and children. The supracardiac shadow is a composite of the shadows of several structures [in the superior mediastinum] . . . ${ }^{87}$ But in England, the royal paediatrician Wilfrid Sheldon wrote in 1943 of "gross enlargement of the thymus, with hypertrophy of the spleen and a general increase in lymphatic tissues . . .. He advised X-ray or radium treatment. ${ }^{88} \mathrm{He}$ did not drop this advice until the eighth edition of his book, in 1962.

In 1949 came an entirely new perspective. It could have been a bombshell. Two American doctors reported the case of a five-year-old child whose thymus had been irradiated soon after birth. The child had developed cancer of the thyroid at the very point where the X-rays had entered its body. ${ }^{89}$

The following year 1950, the journal Cancer reported that of twenty-eight patients under the age of eighteen with cancer of the thyroid, ten had had their thymuses irradiated in infancy. The authors showed that cancer of the thyroid, a rare disease in children, was 100 times commoner in those irradiated early in life than in those who had not been irradiated.90 Somewhat chillingly, they went on to recommend, instead of X-rays, "an aggressive surgical attack on the thyroid glands and cervical nodes." 91

The possible significance of the cancer evidence took some time to penetrate. Many anaesthetists and paediatricians were still supporting the concept of status lymphaticus. A typical textbook still referred to "the pale, flabby child with enlarged tonsils and adenoids and general enlargement of lymph glands and 'night-crowing', in whom the diagnosis is established by X-ray of the chest. ${ }^{92}$ The author suggested that even if the condition is present, death can be avoided by a skilful anaesthetist. Most books continued to describe both the disease and its treatment in the old way but one refreshing new textbook of medicine, The principles and practice of medicine edited by Sir Stanley Davidson, first published in 1952, did not even mention the thymus. Yet the following year Recent

84 H Cohen, 'Thymus gland diseases', in Sir Humphry Rolleston (ed.), British encyclopaedia of medical practice, 12 vols, London, Butterworth, 1936-1952, vol. 12, p. 34.

85 Savill's system of clinical medicine, edited by Agnes Savill and E C Warner, 11th ed., London, E Arnold, 1939, p. 43.

86 Holt's diseases of infancy and childhood, revised by L Emmett Holt, jr, and Rustin McIntosh, 11 th ed., New York and London, D AppletonCentury, 1940, p. 680.

87 Ibid., p. 681.
88 Wilfrid Sheldon, Diseases of infancy, 4th ed., London, J \& A Churchill, 1943, p. 484.

89 I M Scharnagel and G T Pack, 'Multiple basal cell epitheliomas in a 5 year old child', Am. J. Dis. Child., 1949, 77: 647-51.

90 B J Duffy, Jr, and P J Fitzgerald, 'Thyroid cancer in childhood and adolescence: report on 28 cases', Cancer, 1950, 3: 101-832.

91 Ibid, p. 1031.

92 R J Minnitt and John Gillies, Textbook of anaesthetics, 7th ed., Edinburgh, E \& S Livingstone, 1946 , p. $335-6$. 


\section{Ann Dally}

advances in anaesthesia insisted that Moncrieff and others, in spite of attempts to discredit their work, "have definitely established the existence of the syndrome". 93

In 1954, nearly a quarter of a century after the MRC's judgement, Geoffrey Keynes was still pointing out that old beliefs die hard and that status lymphaticus was still very much alive. ${ }^{94}$ This was despite increasingly serious warnings about the dangers of X-rays. In 1955 a book called British practice in radiotherapy, stated : "If the diagnosis of thymic hyperplasia has in such a case been established, X-ray therapy is the treatment of choice." 95 It is somewhat disconcerting to note that one of authors of this article was Geoffrey Keynes, who seemed to have supported the opposite view only the year before.

By 1955 the unusual incidence of cancer in those who had been irradiated was widely known and discussed. ${ }^{96}$ For over forty years it had been known that X-rays could cause cancer. It may seem strange that no one appears to have thought of the possibility of such cancer in irradiated children. Perhaps, like the chloroform deaths, these cases were still rare but the treatment had led to an enormous increase in a rare disease especially since irradiation of the thymus was, for some paediatricians, a routine procedure for normal infants.

There was no immediate scare about this but some took notice. However, the dangers of radical surgery were by now well-known, and luckily the fashion did not revert to that. In 1955 a report in the Journal of the American Medical Association stated that in a series of thyroid cancer cases in children, all fifteen had been irradiated in childhood. ${ }^{97}$ Other reports followed. This was virtually the end of thymic irradiation and of status lymphaticus as a respectable medical diagnosis. By 1969 an article in the Journal of the American Medical Association referred to it as a "pesky medical misconception," 98 which it has remained.

By this time the emphasis had shifted and interest was growing in the thymus from the immunological point of view and in sudden death in infancy as "cot death", later known as Sudden Infant Death Syndrome (SIDS). By this time, too, chloroform was virtually never used. But the belief that "large thymuses" were dangerous was deeply embedded. At least one monograph supporting the concept was published as late as $1959^{99}$ and the subject continued to be treated seriously in widely-used textbooks. ${ }^{100}$ In 1976 evidence was produced that the thymus in cases of cot death was actually smaller than the average size in a control group ${ }^{101}$ yet it continued to be blamed for sudden death in infancy. ${ }^{102}$ Even today references to it appear, especially in medical books written for popular

$93 \mathrm{C}$ L Hewer, Recent advances in anaesthesia and analgesia, 7 th ed., London, J \& A Churchill, 1953 ,

94 Keynes, op. cit., note 59 above, p. 661.

95 Sir Ernest Carling, B W Windeyer and D W Smithers, British practice in radiotherapy, London, Butterworth, 1955, p. 365.

96 C L Simpson, L H Hempelmann, L M Fuller, 'Neoplasia in children treated with X-rays in infancy for thymic enlargement', Radiology, 1955, 64: 840-5.

97 Dwight E Clark, 'Association of irradiation with cancer of the thyroid in children and adolescents', J. Am. med. Ass., 1955, 159: 1007-9.

98 Editorial, 'Thymus Gland', J. Am. med. Ass., 1969, 207: 1438.
99 W N Kemp, Status thymicolymphaticus: $a$ nutritional-endocrine syndrome, publisher not stated, 1959 (reference at Royal Society of Medicine, Tr.14675).

100 For example, W Boyd, Pathology for the physician, 6th ed., London, Henry Kimpton, 1958, pp. 669-71; ibid., 8th ed., 1965, pp. 767-70; H Bailey and $M$ Love, A short practice of surgery, 11th ed., London, H K Lewis, 1959, p. 252.

101 R L Naeye, et al., 'Cardiac and other abnormalities in the sudden infant death syndrome', Am. J. Path., 1976, 82: 1-8.

102 See, for instance, C G Hori, 'Pathology of SIDS', Am. J. Forensic med. Pathol., 1987, 8: 93-6. 


\section{Status Lymphaticus}

consumption. But the practice of thymus irradiation disappeared, as did the diagnosis of status lymphaticus.

\section{Conclusions}

Status lymphaticus was a disease that filled a need that was brought to a head by the occasional, unexpected deaths that occurred under chloroform. It also explained other mysterious deaths. It was widely accepted, described in all the textbooks, then led to controversy and harm to patients, and was finally deemed never to have existed. Gradually the deaths that would have been attributed to it acquired different and separate "causes", including "cot death", SIDS, anaphylactic shock, overwhelming infection, myocarditis and so on. The story shows how medical practitioners and researchers responded to current ideas then and how slowly and patchily this occurred. It shows how, when people are strongly motivated or have fixed beliefs, they are not deflected by evidence and they defend their positions strongly. Eventually the old guard retires and others take their places - often the future old guard. It also shows the way in which the construction of a disease and its treatment can, years later, have important and unforseen consequences. Similar stories are unfolding today. 